\title{
Analisis Efektifitas Pembelajaran Matematika Secara Daring Siswa SMP di Kabupaten Bekasi Selama Masa Pandemi Covid-19
}

\author{
Miftahul Arifin ${ }^{1}$, Siti Chotimah ${ }^{2}$ \\ 1,2 IKIP Siliwangi, Jl. Terusan Jend. Sudirman Kebon Rumput, Cimahi \\ miftahularifin550@gmail.com
}

\begin{abstract}
This study aims to analyze the effectiveness of online mathematics learning (online). In this study, the method used was qualitative descriptive method contucted at one of thestatec junior high schools in West Cikarang, involving 28 students as respondents. The instrument in this study was non-test. The data collection was obtained based on a questionnaire given online through google classroom that were disseminated through google form. The results of this study showed that mathematics learning conducted online at one of the public junior high schools in Cikarang Barat was less effective, this is due to the many obstacles experienced by students. Limited quotas and weak signal in the environvent and the delivery of less effective materials are among the obstacles that students often experience.Based on the results of research conducted solution, to the obstacles experienced by students, namely by providing free quotas from the government, then students look for a location around the house that has a good signal quality to support learning, using appropriate learning media such as interesting learning videos makes students more aware and easy to understand the material deliver by the teacher, especially with the question and answare throught the zoom application, google meet, and other applications that support teacher to be clearer in delivering materials and answering student questions.
\end{abstract}

Keywords: Effective, Online Learning, Covid-19

\begin{abstract}
Abstrak
Penelitian ini bertujuan untuk menganalisis efektifitas pembelajaran matematika secara daring (online). Dalam penelitian ini metode yang digunakan adalah metode deskriptif kualitatif yang dilakukan di salah satu SMP Negeri di Cikarang Barat, dengan melibatkan 28 siswa sebagai responden. Instrumen dalam penelitian ini berbentuk nontes. Pegumpulan data diperoleh berdasarkan kuesioner yang diberikan secara online melalui google classroom yang disebarkan melalui google form. Hasil penelitian ini menunjukan bahwa pembelajaran matematika yang dilakukan secara daring di salah satu SMP Negeri di Cikarang Barat kurang efektif, hal ini dikarenakan banyaknya kendala yang dialami siswa. Terbatasnya kuota dan lemahnya sinyal dilingkungannya serta penyampaian materi yang kurang efektif menjadi salah satu hambatan yang sering dialami siswa Berdasarkan hasil penelitian yang dilakukan solusi dari kendala yang dialami siswa yaitu dengan memberikan kuota gratis yang berasal dari pemerintah, kemudian siswa mencari lokasi sekitar rumah yang memiki kualitas sinyal yang bagus untuk mendukung pembelajaran. Dengan menggunakan media pembelajaran yang sesuai seperti video pembelajaran yang menarik menjadikan siswa lebih semngat dan mudah memahami materi yang disampaikan guru, terlebih dengan adanya tanya jawab melalui aplikasi zoom, google meet, dan aplikasi lain yang mendukung agar guru lebih jelas dalam menyampaikan materi dan menjawab pertanyaan siswa.
\end{abstract}

Kata kunci: Efektif, Pembelajaran Daring, Covid-19

Copyright (c) 2021 Miftahul Arifin, Siti Chotimah

$\square$ Corresponding author: Miftahul Arifin

Email Address: miftahularifin550@gmail.com (Jl. Terusan Jend. Sudirman Kebon Rumput, Cimahi)

Received 14 July 2021, Accepted 30 July 2021, Published 06 August 2021

\section{PENDAHULUAN}

Covid-19 merupakan penyakit akibat virus corona jenis baru yang muncul pada akhir 2019 pertama kali di Wuhan, Cina yang saat ini menyebabkan pandemi hampir di seluruh dunia (Sari, 2020). Saat ini masyarakat di Indonesia sedang dalam masa pandemi Covid-19. Banyak dari bidang di Indonesia yang terkena dampak dari Covid-19 ini salah satunya di bidang pendidikan. Pada tanggal 24 maret 2020 Menteri Pendidikan dan Kebudayaan Republik Indonesia mengeluarkan Surat Edaran Nomor 4 Tahun 2020 Tentang Pelaksanaan Kebijakan Pendidikan Dalam Masa Darurat Penyebaran COVID, dalam Surat Edaran tersebut 
dijelaskan bahwa proses belajar dilaksanakan di rumah melalui pembelajaran daring/jarak jauh dilaksanakan untuk memberikan pengalaman belajar yang bermakna bagi siswa (Dewi, 2020). Pemerintah berharap untuk memutus penyebaran Covid-19 dan juga tidak mengganggu jalannya proses pembelajaran. Dengan adanya surat tersebut, pada bulan maret di Indonesia kini sudah mulai melakukan pembelajaran secara jarak jauh atau pembelajaran daring. Menurut Loviana \& Baskara (Fadila, Nadiroh, Juliana, Zahrah, \& Zulfa, 2021) Pembelajaran daring adalah pelaksanaan pembelajaran antara pendidik dan peserta didik tanpa berkontak fisik dengan memanfaatkan jaringan internet. Pembelajaran daring (E-learning) adalah suatu sistem atau konsep pendidikan yang memanfaatkan teknologi informasi dalam proses belajar mengajar (Rumengan, Lumenta, \& Paturusi, 2019).

Untuk melaksanakan pembelajaran daring ini memang tidak mudah, banyak faktor yang terlibat diantaranya guru, siswa, bahkan orang tua siswa juga mempunyai peran penting dalam terciptanya pembelajaran yang efektif. Pembelajaran daring ini sangat berdampak bagi seluruh guru dan siswa, karena banyak dari siswa yang tidak memiliki fasilitas untuk menunjang pembelajaran daring seperti handphone, laptop, dan juga terbatasnya kuota. Hal ini sejalan dengan Gikas \& Grant (Handarini \& Wulandari, 2020) bahwa Pelaksanaan pembelajaran daring membutuhkan adanya fasilitas sebagai penunjang, yaitu seperti smartphone, laptop, ataupun tablet yang dapat digunakan untuk mengakses informasi dimanapun dan kapanpun.

Matematika merupakan mata pelajaran yang wajib dipelajari disetiap jenjang pendidikan baik itu TK, SD, SMP, SMA bahkan sampai perguruan tinggipun kita mempelajarinya. Matematika merupakan ilmu yang sangat penting untuk dipelajari, ditinjau dari berbagai manfaat yang diberikan untuk memudahkan kita dalam mempelajari materi pembelajaran yang lain ataupun pemanfaatan materi matematika itu sendiri dalam kehidupan sehari-hari (Nurmaenah, Agini, Putri, \& Chotimah, 2020). Pada dasarnya pelajaran matematika tidak selalu tentang angka, tetapi banyak kemampuan yang dapat dikembangkan dari pelajaran matematika salah satunya penyelesaian masalah dalam kehidupan sehari-hari. Hal ini sependapat dengan Chotimah \& Bernard (Chotimah, Ramdhani, Bernard, \& Akbar, 2019) matematika merupakan salah satu pelajaran yang erat kaitannya dengan kehidupan nyata, tidak sedikit hal ataupun masalah yang ada disekeliling kita memerlukan ilmu matematika. Tetapi karena matematika menggunakan banyak rumus nampaknya matematika merupakan salah satu mata pelajaran yang ditakuti dan dianggap rumit serta sulit dipahami oleh beberapa siswa. Hal ini sejalan dengan penelitian yang di lakukan Amallia \& Unaenah (Fauzy \& Nurfauziah, 2021) bahwa masih banyak siswa yang menganggap matematika sebagai pelajaran yang sulit, sehingga menyebabkan siswa mudah menyerah sebelum mempelajari matematika.

Pembelajaran daring terkesan mendadak dalam pelaksanaanya. Hal ini dilihat dari banyaknya kendala yang dihadapi guru maupun siswa saat pelaksanaan pembelajaran daring khususnya mata pelajaran matematika. Dimana mata pelajaran matematika jika dijelaskan secara daring kurang efektif. Berdasarkan permasalahan di atas, diperlukan kajian untuk mengetahui keefektifan dalam pembelajaran daring matematika yang dilaksanakan di jenjang SMP (Sekolah Menengah Pertama). Hal tersebut yang mendasari 
peneliti untuk menganalisis efektifitas pembelajaran daring pada siswa SMP di masa pandemi Covid-19 pada mata pelajaran matematika.

\section{METODE}

Penelitian ini menggunakan metode deskriptif kualitatif yang bertujuan untuk mendeskripsikan efektifitas siswa pada saat pembelajaran daring matematika. Menurut Kriyantono (Akhmad, 2015) Deskriptif kualitatif adalah suatu teknik yang menggambarkan dan menginterpretasikan arti data-data yang telah terkumpul dengan memberikan perhatian dan merekam sebanyak mungkin aspek situasi yang diteliti pada saat itu, sehingga memperoleh gambaran secara umum dan menyeluruh tentang keadaan sebenarnya. Subjek penelitian ini adalah 28 siswa di salah satu SMP Negeri di Cikarang Barat Kabupaten Bekasi. Data tersebut berupa pertanyaan-pertanyaan yang dikirim melalui google classroom kepada responden menggunakan google form, selanjutnya data yang sudah terkumpul dianalisis untuk dideskripsikan.

Tabel 1. Kisi-kisi Angket

\begin{tabular}{|c|l|c|}
\hline No & \multicolumn{1}{|c|}{ Aspek } & Nomor \\
\hline 1 & Pendapat mengenai pembelajaran daring & 1 \\
\hline 2 & $\begin{array}{l}\text { Tingkat pemahaman siswa dengan proses } \\
\text { pembelajaran daring }\end{array}$ & 2 \\
\hline 3 & $\begin{array}{l}\text { Tingkat keefektifan pembelajaran matematika secara } \\
\text { daring }\end{array}$ & 3 \\
\hline 4 & $\begin{array}{l}\text { Hambatan siswa dalam proses pembelajaran daring } \\
\text { matematika }\end{array}$ & 4 \\
\hline 5 & Saran siswa terhadap pembelajaran daring & 5 \\
\hline
\end{tabular}

\section{HASIL DAN DISKUSI}

Responden dari penelitian ini berjumlah 28 siswa. Rekapitulasi responden tergambar pada Tabel 1.

Tabel 2. Rekapitulasi Responden

\begin{tabular}{|c|c|c|c|}
\hline No & Kelas & Persentase & Jumlah siswa \\
\hline 1 & 9.6 & $14 \%$ & 4 \\
\hline 2 & 9.7 & $29 \%$ & 8 \\
\hline 3 & 9.8 & $32 \%$ & 9 \\
\hline 4 & 9.9 & $25 \%$ & 7 \\
\hline & Total & $100 \%$ & 28 \\
\hline
\end{tabular}

Berdasarkan Tabel di atas bahwa responden terdiri dari dua puluh delapan siswa yang termasuk dalam 4 kelas, diantaranya empat siswa kelas 9.6 dengan persentase 14\%, delapan siswa kelas 9.7 dengan persentase 29\%, sembilan siswa kelas 9.8 dengan persentase tertinggi yaitu 32\%, dan terakhir tujuh siswa kelas 9.9 dengan persentase $25 \%$. Jumlah siswa yang paling banyak mengisi kuisoner adalah siswa kelas 9.8 sebanyak sembilan siswa dan yang paling sedikit siswa kelas 9.6 sebanyak empat siswa. 


\section{Perasaan Mengenai Pembelajaran Matematika Secara Daring (Online)}

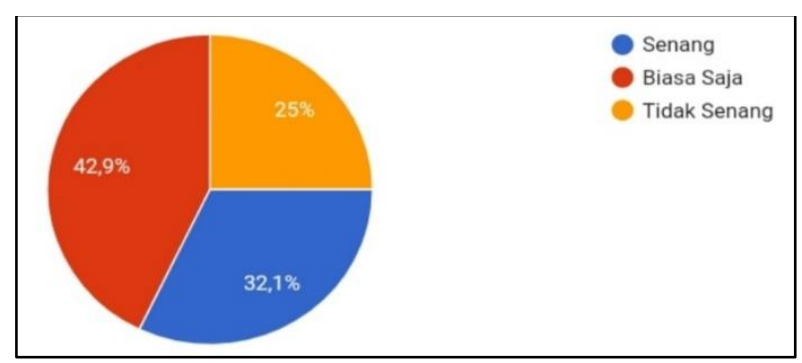

Gambar 1. Perasaan mengenai pembelajaran matematika secara daring (online)

Berdasarkan gambar 1, sebanyak 42,9\% siswa mempunyai perasaan yang biasa saja terhadap pembelajaran matematika secara daring, sebanyak $32,1 \%$ siswa senang, dan sebanyak $25 \%$ siswa tidak senang. Dilihat dari jawaban diatas banyak siswa yang mempunyai perasaan yang biasa saja terhadap pembelajaran matematika secara daring ini, karena siswa hanya mengikuti anjuran dari pemerintah yaitu untuk tetap dirumah dan melakukan pembelajaran secara daring. Siswa yang merasa senang terhadap pembelajaran daring, karena bagi mereka pembelajaran daring ini bisa di lakukan dimana saja sehingga mereka bisa mencari referensi lain seperti dari buku, bahkan internet. Salah satu alasan siswa yang tidak senang dengan pembelajaran daring ini, mereka merasa bosan dan terkadang tidak mengerti dengan apa yang dijelaskan guru terlebih ketika tugas yang diberikan banyak.

\section{Pemahaman dalam Pembelajaran Matematika Secara Daring (Online)}

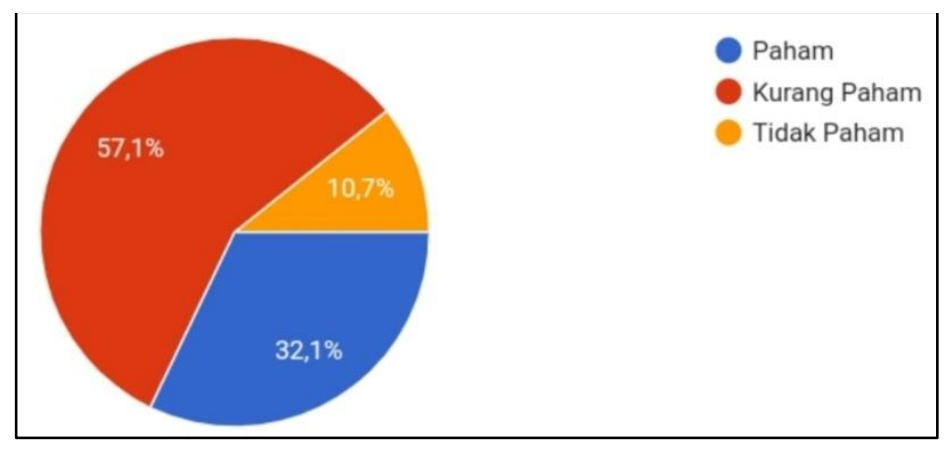

Gambar 2. Pemahaman dalam pembelajaran matematika secara daring (online)

Berdasarkan gambar 2, sebanyak 57,1\% siswa kurang paham dengan pembelajaran matematika yang dilakukan secara daring, sebanyak 32,1\% siswa paham, dan sebanyak 10,7\% tidak paham. Dilihat dari jawaban diatas kebanyakan siswa kurang paham dengan pembelajaran matematika yang dilakukan secara daring. Hal ini dikarenakan tidak bertemu langsung dengan guru yang membuat siswa kesulitan dalam menanyakan sesuatu yang tidak dimengerti, walaupun sebenarnya siswa bisa menanyakan gurunya secara daring tetapi itu masih tetap tidak dimengerti oleh siswa. Hal ini sesuai dengan pendapat Amelia, Chotimah, \& Putri (Amelia, Chotimah, \& Putri, 2021) Siswa masih kesulitan untuk memahami materi dan masih memerlukan bimbingan guru sehingga siswa sulit belajar secara mandiri. Guru sudah melakukan berbagai cara seperti melalui chat whatsapp, voice note whatsapp, maupun video call whatsapp. Tetapi banyak dari 
siswa yang kurang mengerti dan terlebih lagi untuk melakukan video call terkadang tidak bisa dengan alasan sinyal dan kuota. Siswa akhirnya tidak banyak yang bertanya karena memang sulit untuk bertanya melalui online. Kebanyakan dari siswa kurang paham dengan langkah-langkah dalam pengerjaan soal matematika. Hal ini sejalan dengan pendapat Badraeni, Ayu Pamungkas, Hidayat, Eti Rohaeti, \& Tanu Wijaya (Huzaimah \& Risma, 2021) Siswa belum paham tentang langkah-langkah soal dan indikator kemampuan pemahaman yaitu menerapkan rumus dalam perhitungan. Peran guru sangat penting dalam menumbuhkan semangat dan minat siswa dalam melakukan pembelajaran secara daring. Hal ini sejalan dengan pendapat Anugrahana (Huzaimah \& Risma, 2021) bahwa Peran guru sangat penting dalam menciptakan strategi pembelajaran yang baik, menyajikan bahan ajar yang menarik, agar siswa tidak jenuh dan aktif berpartisipasi dalam proses belajar.

Tidak sedikit juga siswa yang paham dengan pembelajaran matematika secara daring ini. Siswa dapat dengan mudah mengakses video pembelajaran seperti pembahasan yang terdapat pada youtube apabila siswa menemukan kesulitan dalam mempelajari materi. Hal ini sejalan dengan pendapat Fleck, dkk (Suwarno, 2017) Youtube sebagai alat pendidikan melahirkan perhatian yang besar untuk menciptakan praktek-praktek pendidikan terbaik. Tentu hal tersebut membuat siswa jadi lebih paham untuk mempelajari materi dan menjawab soal-soal yang diberikan oleh guru. Tetapi untuk mengakses youtube memerlukan kuota dan sinyal yang bagus, maka dari itu banyak dari siswa tidak bisa mengakses youtube karena keterbatasan kuota dan buruknya sinyal dilingkungannya yang membuat siswa jadi kurang memahami dalam mempelajari materi dan juga menjawab soal-soal yang diberikan oleh guru.

\section{Efektifitas dalam Pembelajaran Matematika Secara Daring (Online)}

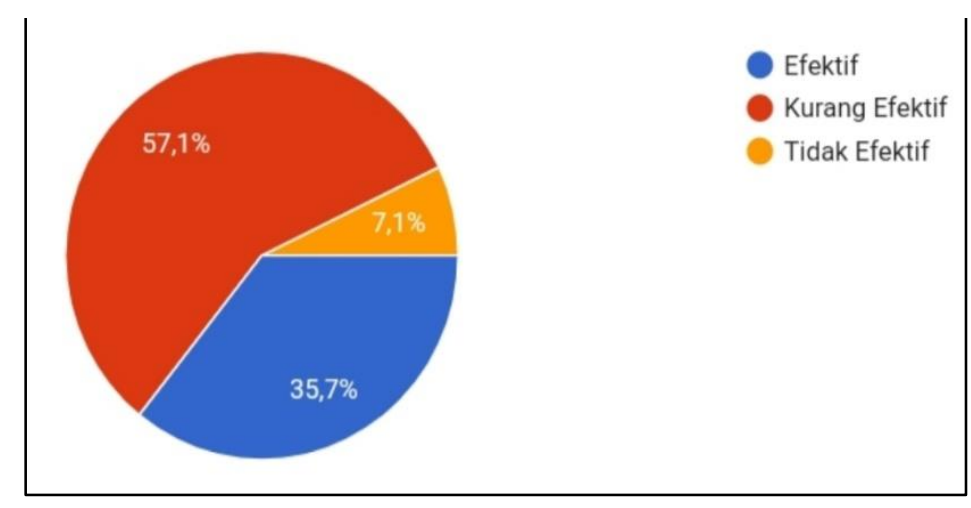

Gambar 3. Efektifitas dalam pembelajaran matematika secara daring (online)

Berdasarkan gambar 3, sebanyak 57,1\% siswa menjawab kurang efektif, 35,7\% siswa menjawab efektif dan 7,1\% siswa menjawab tidak efektif. Dilihat dari jawaban diatas bahwa pembelajaran matematika secara daring kurang efektif. hal ini dikarenakan terdapat faktor yang mempengaruhi jalannya pembelajaran matematika secara daring, seperti sulit untuk memahami materi. Hal ini sejalan dengan penelitian yang dilakukan oleh Tasdik \& Amelia (Tasdik \& Amelia, 2021) bahwa pelajaran matematika tidak cocok dijelaskan lewat pembelajaran daring karena sulitnya memahami pelajaran matematika. Tidak sedikit pula dari siswa yang berpendapat bahwa melakukan pembelajaran matematika secara daring itu efektif. Selain 
untuk memutus penyebaran Covid-19 dan mengikuti anjuran pemerintah untuk tetap dirumah, siswa juga dapat lebih fokus belajar di rumah dan merasa aman. Hal ini sejalan dengan penelitian yang dilakukan oleh Tasdik \& Amelia (Tasdik \& Amelia, 2021) bahwa dengan pembelajaran daring ini siswa bisa lebih fokus belajar di rumah dan lebih aman dari penyebaran virus Covid-19.

\section{Kendala dan Saran Siswa Terhadap Pembelajaran Matematika Secara Daring (Online)}

Tabel 3. Kendala dan Saran siswa terhadap pembelajaran matematika secara daring

\begin{tabular}{|l|l|c|}
\hline NO & \multicolumn{1}{|c|}{ Jawaban Siswa } & $\begin{array}{c}\text { Jumlah } \\
\text { Siswa }\end{array}$ \\
\hline 1 & Koneksi Jaringan yang tidak stabil & 8 \\
\hline 2 & Keterbatasan kuota & 8 \\
\hline 3 & $\begin{array}{l}\text { Memori telepon yang tidak cukup karena harus menyimpan file atau video } \\
\text { pembelajaran }\end{array}$ & 5 \\
\hline 4 & Pemberian tugas jangan terlalu banyak agar tidak malas untuk belajar & 4 \\
\hline 5 & $\begin{array}{l}\text { Pada proses pembelajaran matematika secara daring, guru menggunakan media } \\
\text { pembelajaran yang disesuaikan dengan materi pada matapelajaran matematika }\end{array}$ & 3 \\
\hline
\end{tabular}

Berdasarkan Tabel 3, hasil penelitian yang telah dilakukan terhadap 28 siswa kendala utama yaitu pengaruh sinyal dan kuota. Hal ini pasti sangat berpengaruh karena dalam pembelajaran daring faktor yang paling penting yaitu jaringan internet dan kuota. Kedua hal tersebut saling berkaitan disaat kuota banyak tetapi jaringan internet jelek itu akan menghambat pembelajaran, dan sebaliknya jika jaringan internet bagus tetapi kuota tidak memadai maka tidak akan bisa mengikuti pembelajaran daring yang harus selalu terhubung dengan internet. Hal ini sejalan dengan pendapat Brier (Brier, 2020) sinyal/koneksi ini adalah faktor terpenting dalam pembelajaran daring, jika tidak ada sinyal/koneksi maka siswa terhambat dalam mengunduh tugas yang diberikan oleh guru dan mengirimkan tugasnya. Kendala lain yang disampaikan oleh beberapa siswa yaitu kurangnya pemahaman pada materi. Dikarenakan tingkat pemahaman siswa berbeda-beda dan metode yang guru gunakan pada saat pembelajaran daring. Hal ini sejalan dengan (Abdullah, Achmad, \& Fahrudin, 2020) Salah satu pusat kendala pembelajaran online matematika yaitu siswa sulit memahami materi yang disampaikan guru lewat media online.

Berdasarkan wawancara yang dilakukan terhadap salah satu guru mata pelajaran matematika di sekolah tersebut, bahwa sebagian besar orang tua siswa memiliki ekonomi menengah ke bawah. Banyak dari mereka yang orang tuanya bekerja sebagai buruh, pedagang keliling, bahkan petani, sehingga mereka tinggal di pelosok yang jaringan internetnya sulit terjangkau. Tak hanya itu, fasilitas penunjang untuk pembelajaran daring pun banyak dari mereka yang tidak memiliki salah satunya smartphone.

Setelah dianalisis dari permasalahan di atas, Pembelajaran daring yang dilakukan selama masa pandemic Covid-19 kurang efektif. Untuk menjadikan pembelajaran daring lebih efektif dan membuat 
siswa lebih semangat dalam mengikutinya, guru diharapkan untuk memilih metode pembelajaran yang tepat dan sesuai dengan keadaan pembelajaran daring serta menyajikan materi lebih kreatif salah satunya dengan menggunakan media pembelajaran yang sesuia agar siswa lebih tertarik untuk mengikuti pembelajaran. Karena banyak dari mereka yang tinggal ditempat yang jaringan internetnya sulit terjangkau atau tidak stabil maka sebelum pembelajaran berangsung diharapkan siswa mencari lokasi sekitar rumah yang memiliki kualitas sinyal yang bagus. Pemerintah juga ikut serta dalam meningkatkan pembelajaran menjadi lebih efektif dengan memberikan kuota secara gratis kepada siswa maupun guru. Jika siswa tidak memiliki fasilitas yang menunjang untuk pembelajaran daring, maka pihak sekolah pun melaksanakan pembelajaran secara luring baik disekolah maupun home visist dengan catatan mengikuti protocol kesehatan. Dengan begitu, siswa yang tidak memiliki fasilitas bisa tetap mengikuti pembelajaran.

\section{KESIMPULAN}

Berdasarkan hasil analisis, disimpulkan bahwa dalam pembelajaran daring matematika di masa pandemi Covid-19 ini kurang efektif. Terbatasnya kuota dan lemahnya sinyal dilingkungannya serta penyampaian materi yang kurang efektif menjadi salah satu hambatan yang sering dialami siswa. Salah solusi dari kendala yang dialami siswa yaitu dengan memberikan kuota gratis yang berasal dari pemerintah, kemudian siswa mencari lokasi sekitar rumah yang memiki kualitas sinyal yang bagus untuk mendukung pembelajaran. Dengan menggunakan media pembelajaran yang sesuai seperti video pembelajaran yang menarik menjadikan siswa lebih semngat dan mudah memahami materi yang disampaikan guru, terlebih dengan adanya tanya jawab melalui aplikasi zoom, google meet, dan aplikasi lain yang mendukung agar guru lebih jelas dalam menyampaikan materi dan menjawab pertanyaan siswa.

\section{UCAPAN TERIMA KASIH}

Ucapan terima kasih peneliti sampaikan kepada beberapa pihak yang sudah membantu dalam menyelesaikan penelitian ini khususnya kepada ibu Siti Chotimah yang telah membimbing dalam penelitian ini. Kemudian terima kasih juga kepada pihak sekolah yang telah bersedia memberikan izin untuk melakukan observasi. Dan juga kepada pihak jurnal Cendekia yang telah membantu dalam mempublish artikel.

\section{REFERENSI}

Abdullah, A. W., Achmad, N., \& Fahrudin, N. C. (2020). DESKRIPSI HASIL BELAJAR MATEMATIKA SISWA MELALUI PEMBELAJARAN DARING PADA POKOK BAHASAN BANGUN RUANG SISI DATAR. 8(2).

Akhmad, K. A. (2015). Pemanfaatan Media Sosial bagi Pengembangan Pemasaran UMKM (Studi Deskriptif Kualitatif pada Distro di Kota Surakarta). Duta.Com, 9(September), 43-54.

Amelia, R., Chotimah, S., \& Putri, D. (2021). Pengembangan Bahan Ajar Daring Pada Materi Geometri SMP dengan Pendekatan Project Based Learning Berbantuan Software Wingeom. Jurnal Cendekia: Jurnal Pendidikan Matematika, 5(1), 759-769.

Brier, J. (2020). Efektivitas Pembelajaran Daring Dalam Pembelajaran Bahasa Indonesia di Kelas II A MI 
Unggulan Miftahul Huda Tumang Cepogo Boyolali. 21(1), 1-9.

Chotimah, S., Ramdhani, F. A., Bernard, M., \& Akbar, P. (2019). PENGARUH PENDEKATAN MODELELICITING ACTIVITIES TERHADAP KEMAMPUAN BERPIKIR KRITIS MATEMATIK SISWA SMP NEGERI DI KOTA CIMAHI. Journal On Education, 01(02), 68-77.

Dewi, W. A. F. (2020). Dampak COVID-19 terhadap Implementasi Pembelajaran Daring di Sekolah Dasar. Edukatif: Jurnal Ilmu Pendidikan, 2(1), 55-61.

Fadila, R. N., Nadiroh, T. A., Juliana, R., Zahrah, P., \& Zulfa, H. (2021). Kemandirian Belajar Secara Daring Sebagai Prediktor Hasil Belajar Mahasiswa Pendidikan Matematika UIN Sunan Kalijaga. 05(02), 880-891.

Fauzy, A., \& Nurfauziah, P. (2021). Kesulitan Pembelajaran Daring Matematika Pada Masa Pandemi COVID-19 di SMP Muslimin Cililin. Jurnal Cendekia : Jurnal Pendidikan Matematika, 5(1), 551561.

Handarini, O. I., \& Wulandari, S. S. (2020). Pembelajaran Daring Sebagai Upaya Study From Home (SFH) Selama Pandemi Covid 19. Jurnal Pendidikan Administrasi Perkantoran (JPAP), 8(3), 496-503.

Huzaimah, P. Z., \& Risma, A. (2021). Hambatan yang Dialami Siswa Dalam Pembelajaran Daring Matematika Pada Masa Pandemi COVID-19. 05(01), 533-541.

Nurmaenah, N. C., Agini, S., Putri, Y., \& Chotimah, S. (2020). Analisis Minat Belajar Siswa Pada Materi KPK Dan FPB Menggunakan Pendekatan Saintifik Berbantuan Aplikasi Visual Basic Excel (VBE). Journal on Education, 2(4), 275-282.

Rumengan, I. M., Lumenta, A. S. M., \& Paturusi, S. D. E. (2019). Pembelajaran Daring Pendidikan dan Pelatihan Aparatur Sipil Negara Badan Pengembangan Sumber Daya Manusia Papua Barat. Jurnal Teknik Informatika, 14(3), 303-312.

Sari, M. K. (2020). Sosialisasi tentang Pencegahan Covid-19 di Kalangan Siswa Sekolah Dasar di SD Minggiran 2 Kecamatan Papar Kabupaten Kediri. Jurnal Karya Abdi, 4(1), 80-83.

Suwarno, M. (2017). Potensi Youtube Sebagai Sumber Belajar Matematika. Pi: Mathematics Education Journal, 1(1), 1-7.

Tasdik, R. N., \& Amelia, R. (2021). Kendala Siswa SMK dalam Pembelajaran Daring Matematika di Situasi Pandemi COVID-19. Jurnal Cendekia : Jurnal Pendidikan Matematika, 5(1), 510-521. 